\title{
The impact of leadership and organizational context on the acceptability of unethical HRM practices
}

\author{
Eduardo Simões ${ }^{1}, 2$, Ana Patrícia Duarte ${ }^{1,3}$, \& Patrícia Nunes ${ }^{1}$ \\ ${ }^{1}$ Instituto Universitário de Lisboa (ISCTE-IUL), Lisbon, Portugal \\ 2 DINÂMIA'CET, Lisboa, Portugal \\ ${ }^{3}$ Business Research Unit (BRU-IUL), Lisboa, Portugal
}

\begin{abstract}
Recent research has found that human resource (HR) practitioners judge the acceptability of ethically questionable practices based on the importance their organization attributes to ethical infrastructure (e.g., codes of conduct) and corporate social responsibility practices. This study sought to evaluate the effects of ethical leadership and the aforementioned factors on other non-HR organizational actors. More specifically, this research examined how these individuals judge the acceptability of three ethically dubious HR management practices: discrimination, disregard for the individual, and favoring those in power. Results obtained from data collected through an online survey indicate that ethical leadership is negatively associated with the acceptability of all three practices. Individuals in organizations with a stronger ethical infrastructurealso find discrimination and disregard for the individual less acceptable. The same is true of participants in organizations perceived as more socially responsible regarding employees and economic aspects.
\end{abstract}

Keywords: Ethics; human resource management practices; ethical infrastructure; corporate social responsibility; ethical leadership.

0 impacto da liderança e do contexto organizacional na aceitabilidade ética de práticas de Gestão de Recursos Humanos: Pesquisa recente verificou que os profissionais de Recursos Humanos (RH) julgam a aceitabilidade de práticas eticamente questionáveis com base na importância que a sua organização atribui à infraestrutura ética e às práticas de responsabilidade social. Este estudo avaliou os efeitos da liderança ética e dos fatores mencionados sobre o modo como outros atores organizacionais, que não os profissionais de RH, julgam a aceitabilidade de três práticas eticamente duvidosas de gestão de RH: discriminação, desrespeito pelo indivíduo e favorecimento de quem está no poder. Os resultados indicam que a liderança ética está negativamente associada à aceitabilidade das três práticas. Os indivíduos provenientes de organizações nas quais a infraestrutura ética é mais forte também consideram as práticas de discriminação e de desrespeito pelo indivíduo menos aceitáveis. 0 mesmo é verdade para os participantes de organizações percebidas como mais socialmente responsáveis em relação aos trabalhadores e no domínio económico.

Palavras-chave: Ética; práticas de gestão de recursos humanos; infraestrutura ética; responsabilidade social das organizações; liderança ética.

The praxis and discourse currently prevailing in human resource management (HRM) tend to favor strict economic rationality goals and emphasize the importance of HRM interventions contributing to organizations' profitability and effectiveness. Given the traditional image of HRM as the promoter of employee welfare in organizations, this tendency appears to be paradoxical as it underestimates the importance of ethics in the employment relationship. Concurrently, the responsibility for ethical scandals on a global economy scale, particularly in financial services, has been ascribed almost exclusively to chief executive officers and chief financial officers, apparently leaving HRM to escape any scrutiny (Parkes \& Davis, 2013).

However, ethics are inherent to the central objectives of HRM (e.g., Pinnington et al., 2007; Wooten, 2001). Recruitment, training programs, and performance appraisals are some areas in which, customarily, ethical vigilance is required. In addition, HRM currently has new and more complex ethical problems with which to deal. For instance, profound changes in organizational settings in recent decades ${ }^{1}$ Correspondence address: Ana Patrícia Duarte, Av. das Forças Armadas, Edifício Sedas Nunes, Sala 2w17, 1649-026 Lisbon, Portugal. E-mail:
patricia.duarte@iscte-iul.pt. This work was supported by Fundação para a Ciência e a Tecnologia grant (UID/GES/00315/2013). 
(e.g., the increasing diversity of the workforce) have challenged human resources (HR) practitioners, who have to deal with problems of ethnic, gender, or age discrimination.

Critical evaluations of HRM's current state of affairs have indicated a strong tendency toward the depersonalization and increasing dehumanization of employment relationships (e.g., Dale, 2012; de Gama et al., 2012; Jac et al., 2012), and state that HRM is very often aligning with general management strategies that blindly favor economic outcomes over fairness or employee wellbeing. Thus, in this critical view, dominant HRM approaches seem to be shifting to a mentality that effectively minimizes the ethical scrutiny of employer-employee relationships (Van Buren et al, 2011).

The results of a recent study (Simões et al., 2019) indicate that contextual variables, such as corporate social responsibility (CSR) and ethics standards, predict how HR practitioners judge the acceptability of their own ethically dubious HRM practices. More specifically, the cited research found that unethical HRM practices are less acceptable to HR professionals in organizations that are perceived as more socially responsible and that give great importance to ethics codes and rules. The present study sought to complement and develop the research on this topic further by focusing on the perceptions of other organizational actors besides HR practitioners. As the conceptual model of this study depicted in Figure 1 shows, this research thus analyzed the possible effects of the previously studied contextual variables (i.e, existence of a formal code of ethics, scope of an organization's ethics program, perceived importance of an organization's ethics program, perceived corporate social responsibility) and supervisors' ethical leadership on non-HR professionals' acceptability of ethically dubious HRM practices.

\section{HRM and Organizational Ethics}

Some overly simplistic approaches have portrayed ethical decision-making issues in organizations as a problem of "bad apples" so that ethical failures are seen as deliberate choices resulting from individuals' character faults. However, empirical evidence provides a different, more complex picture. Failures do not always stem from individuals' conscious decisions to subvert moral norms for two primary reasons. First, recognizing ethical problems in given situations is not easy (e.g., Bersoff, 1999; Treviño \& Brown, 2004), and, second, ethical scrutiny requires making complicated inferences concerning an action's consequences for others (e.g., Chugh et al., 2005).

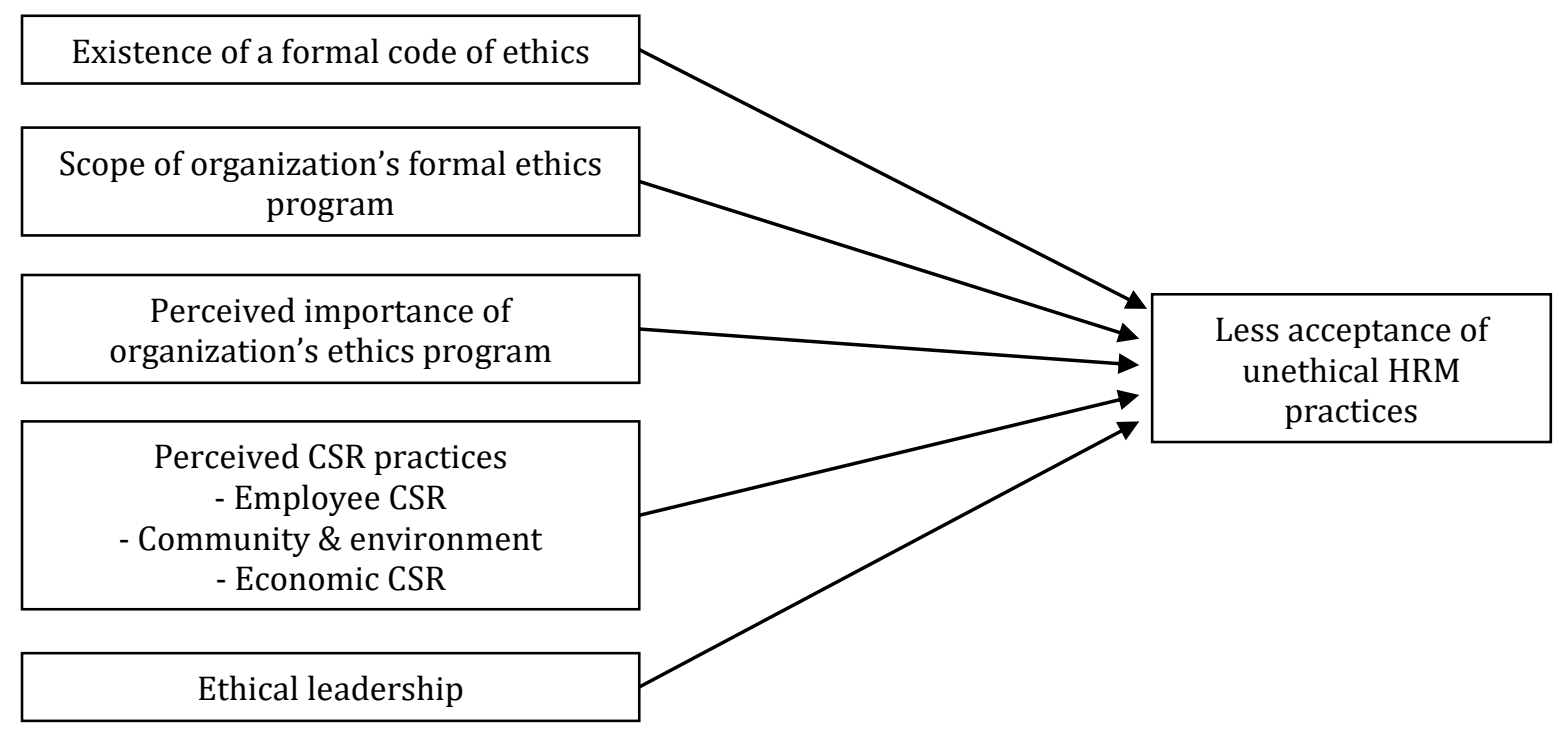

Figure 1. Conceptual model

Even if some individual characteristics affect this process, ethical behaviors within organizations are determined by multiple factors (Kish-Gephart et al., 2010). Ethical judgment is, therefore, strongly influenced by contextual dynamics (e.g., Tenbrunsel \& Messick, 1999; Treviño \& Weaver, 2001). For instance, individuals rely on implicit clues from their organizational environment to evaluate the moral relevance of situations. 


\section{Contextual Factors}

Due to the multiple roles played by HR professionals, this contextual influence can be crucial in HRM, which is inherently associated with ethical dilemmas (Wooten, 2001). The presence of formal ethical norms and values acknowledged in organizational culture, for example, provides implicit guidelines for dealing with ethically dubious HRM practices. Ethical infrastructure (Tenbrunsel et al., 2003), namely, sanctions and communication systems designed to ensure organizations' ethical effectiveness, may be decisive in this context, guiding judgements made about HR professionals' unethical practices.

A strong normative framework, including sanctioning systems, seems to be positively related to ethical behavior (e.g., Tenbrunsel et al., 2003). However, the relationship between ethical infrastructure and ethical behavior in organizations is neither linear nor direct. Some of the early research on the effects of ethical codes of conduct on ethical behavior reported an insignificant relationship (e.g., Brief et al., 1996; Cleek \& Leonard, 1998). More recently, the consideration of contextual and individual factors that can influence compliance to codes (e.g., Schwartz, 2001) has been gradually suggesting a positive effect on behavior and attitudes of organizational actors. In sum, although the impact of formal codes of conduct is difficult to assess empirically (Treviño \& Nelson, 2007) because of their diverse content and implementation context, yet the mere existence of an ethics code is associated, to some degree, with refusals to engage in unethical behaviors (e.g., Kaptein, 2011; Kaptein \& Schwartz, 2008; McCabe et al., 1996; McKinney et al., 2010). Conjecting that this association might be extended to HRM unethical practices, and despite mixed evidence in the literature, we proposed the following hypothesis:

Hypothesis 1: The existence of a code of ethics in an organization is negatively related to the acceptability of unethical HRM practices among non-HR employees.

Beyond the mere existence of an ethics code, the nature and content of its practical extensions through different elements of actions can make a difference in the code's impact on organizational actors. For example, the number of components and composition of ethics programs reduces the frequency of observed unethical behaviors (Kaptein, 2015). More specifically, the scope of ethics programs (e.g., ethics training, accountability policy communication, or ethics report lines) can impact the degree to which individuals accept-or not-these practices. These considerations led us to formulate the following hypothesis:

Hypothesis 2: The scope of an organization's ethics program is negatively related to the acceptability of unethical HRM practices among non-HR employees.

Previous studies' results (Simões et al., 2019) indicate that the way organizations use their ethics infrastructure, such as proactively supporting an ethics code, impacts individuals' ethical behavior and awareness. Thus, the present research posited that the importance given to organizations' ethical norms and procedures shapes the process of judging how acceptable ethical dubious HRM practices are. Therefore, we proposed that:

Hypothesis 3: The perceived importance of an organization's ethics program is negatively related to the acceptability of unethical HRM practices among non-HR employees.

\section{Corporate Social Responsibility}

CSR is a multidimensional construct that comprises a broad range of principles, policies, and practices that appear to further the social good (Aguinis, 2011; Freeman, 1984; McWilliams \& Siegel, 2001). CSR further implies that organizations maximize the creation of value for all human and non-human stakeholders and society at large, as well as mitigating the negative impacts of their business operations (European Commission, 2011; Turker, 2009).

Employees constitute a primary stakeholder for any organization, and, as such, they must be considered in both CSR and HRM policies. Various authors have thus proposed that HR professionals have a key role in CSR (Barrena-Martínez et al., 2017; Sharma et al. , 2009). That is, they can help organizations address CSR and ethical challenges more efficiently (Jamili et al., 2015; Voegtlin \& Greenwood, 2016) by serving as ethical stewards (Caldwell et al., 2011).

CSR is not usually considered a formal element of organizations' ethical infrastructure, but it provides important support for organizational members' ethical orientation. This occurs because companies' engagement in socially responsible practices signals the firms' values system and ethical priorities, thereby influencing the attention of their members pay to ethical issues (Florea et al., 2013; Guerci et al., 2015). Evidence has been found that CSR highlights norms regarding the fair treatment of individuals both within and outside organizations (Rupp, 2011; Rupp et al., 2006), providing relevant criteria for those judging the acceptability of organizational practices. 
Accordingly, organizational members' general perceptions of CSR practices may influence how specific organizational actors deal with ethical issues (Turner et al., 2019). This can be particularly true for employee-related CSR practices and their effect on how HRM practices are judged by employees (Simões et al., 2019). Therefore, we expected the following to be true:

Hypothesis 4: An organization's perceived CSR practices (i.e., employee, community and environment, and economic CSR) are negatively related to the acceptability of unethical HRM practices among non-HR employees.

\section{Ethical Leadership}

Organizations' formal rules and contextual clues do not directly influence behavior, but how individuals use them does. In organizations, leaders can-or may fail to-breathe life into norms through the dynamics of leaders' relationships with followers. Research on organizational ethics has shown that the way leadership is exercised is crucial to understanding organizational actors' behaviors and perceptions (Treviño \& Brown, 2014).

Ethical leadership involves demonstrating appropriate behavior through leaders' actions and communication with followers (Brown et al., 2005). That is, in addition to being moral, leaders are ethical when they have a positive influence on their followers, serving as a model within social learning processes (Brown et al., 2005). Leaders can also use a transactional approach involving reward and punishment to stimulate ethical conduct in followers (Treviño et al., 2003).

Some specific leadership behaviors are related to trait-like individual characteristics, such as behaving honestly and demonstrating integrity. Researchers have proposed that these characteristics are important components of ethical leadership because they can foster reciprocity in followers by modeling ethical and constructive behaviors not only through leaders' practices but also entire organizations.

Ethical leadership has been found to relate positively to trust and several performance and motivation outcomes, such as normative and affective commitment (see Den Hartog [2015] for a review of relevant research). This type of leadership also has a direct influence on subordinates' ethical and prosocial behaviors (e.g., Brown \& Treviño, 2006). A recent meta-analytical study (Bedi et al., 2016) confirmed that ethical leadership has a positive relationship with followers' ethical behavior. In addition to the contextual factors discussed above, ethical leadership may affect organizational members' acceptability of ethically dubious HRM practices. Thus, the following hypothesis was proposed for the present study:

Hypothesis 5: Perceived ethical leadership is negatively related to the acceptability of unethical HRM practices among non-HR employees.

\section{METHOD}

\section{Sample and Procedure}

An electronic self-report survey was administered to a convenience sample of 191 employees from various organizations, being the inclusion criteria having at least six months of tenure in organization and reporting to a direct supervisor/leader. The research goals were presented on the questionnaire's first page, which also included guarantees of confidentiality and anonymity of respondents. Informed consent was required for inclusion in the study, and participation was voluntary. The respondents were between 22 and 63 years old (mean $[\mathrm{M}]=37.20$; standard deviation $[\mathrm{SD}]=10.45)$, and $56.0 \%$ were females. Some surveyed individuals $(17.3 \%$ ) had completed 12 years or less of schooling, but most (82.7\%) had a higher education degree. Regarding job tenure, respondents had been employed in their organizations for an average of 9.20 years $(\mathrm{SD}=9.19$ years; minimum $=0.50$ years; maximum $=40$ years). Most respondents worked for a private organization $(73.8 \%)$ with more than 250 employees $(53.4 \%)$.

\section{Variables and Measures}

Existence of Ethics Code. The existence of a code of ethics (i.e., a formal document articulating the organization's values and standards of conduct) is a structural component of the ethical infrastructure of the organization. It was assessed via a dichotomous question to which respondents answered either "No" or "Yes," which were scored 0 or 1, respectively (e.g., Kaptein, 2009, 2015; Simões et al., 2019; Treviño \& Weaver, 2001). Most respondents (82.19\%) indicated that their organizations have a code of ethics or a similar formal document.

Scope of Ethics Program. To develop an indicator of the scope of ethics programs within organizations, as a crucial formal component of the organizational ethical infrastructure, the respondents were asked if five additional elements of an ethics program existed in addition to the code of ethics (Kaptein, 2009, 
2015; Simões et al., 2019; Treviño \& Weaver, 2001; Weaver et al., 1999). These were ethics code training, clear rules for sanctions for misconduct, an anonymous and confidential "hotline" on ethical issues, a system of monitoring compliance with the ethics code, and a manager responsible for the code.

Responses were given as "No" or "Yes," which were scored 0 or 1, respectively. A composite variable was created by adding together the number of ethics program elements reported by respondents, ranging from 1 (i.e., the existence of a code of ethics) to 6 (the existence of a code of ethics plus the five other elements). Higher scores reflect broader ethics programs present in the respondents' organizations.

Perceived Importance of Ethics Program. This variable is part of the "organizational climates that support the infrastructure" (Tenbrunsen et al., 2003, p. 286). It was measured with three items adapted from the relevant literature (e.g., Simões et al., 2019; Treviño \& Nelson, 2007) (e.g., "Employees are aware of the existence of a code of ethics [or similar document] in the organization."; alpha $[\alpha]=.89$ ). The respondents were asked to indicate to what extent each statement was true of their organization, using a 5 -point response scale ( 1 = "Not at all"; 5 = "Totally"). To obtain a composite score, the items' scores were averaged. Higher scores reflect a perception of higher importance given to an organization's ethics program.

Perceived CSR Practices. The respondents' perceptions regarding their organizations' engagement in CSR practices were measured using 16 items from a perceived CSR scale developed and validated by Duarte (2011). The items were organized into three dimensions. The first is employee CSR, which includes practices directed to improving employees' wellbeing and quality of life at work, such as promoting gender equality (seven items; $\alpha=.72$ ). The second dimension is community and environment CSR, which includes practices contributing to environmental conservation and protection and community welfare, such as supporting social causes (six items; $\alpha=.94$ ). The last dimension is economic CSR, which encompasses practices addressing responsible economic performance, such as striving to be the best organization in the relevant business sector (three items; $\alpha=.69$ ).

The participants were asked to indicate their level of agreement with each statement using a 5point response scale ( 1 = "Totally disagree"; 5 = "Totally agree"). A composite variable was created for each dimension by averaging the pertinent items. Higher scores represent perceptions of organizations' stronger engagement in CSR practices.

Ethical Leadership. The Ethical Leadership Scale developed by Brown et al. (2005) was used to evaluate participants' perceptions of their leaders (direct supervisors) ethical behavior. This is a 10-item unidimensional measure that assesses diverse types of ethical leadership behaviors such as principled and fair decision-making, open two-way communication with followers, ethical role modeling, and punishment of unethical behavior (e.g., "Disciplining employees who violate ethical standards."; $\alpha=.94$ ). Items were rated on a 5-point response scale ( 1 = "Strongly disagree"; 5 = "Strongly agree"). To obtain a composite ethical leadership score, the items' scores were averaged. Higher scores reflect more positive evaluations of direct supervisors' ethical actions and behaviors.

Acceptability of Unethical HRM Practices. This variable was measured with 11 items adapted from Simões et al.'s (2019) study. These were organized in three dimensions. The first is discrimination practices assessed by four items (e.g., "Selecting men for roles that involve a heavier workload."; $\alpha=.65$ ). The second dimension is practices showing a disregard for the individual, evaluated by two items related to the discrimination of individuals based in personal characteristics such as gender, ethnic background or higher education institution attended (e.g., "Repeating to other colleagues information confided by an employee."; Pearson's correlation coefficient $=.43 ; p<.01]$ ). The last dimension is practices favoring those in power measured with five items related to ignoring the misbehavior of those in power or facilitating processes that somewhat include them (e.g., "Facilitating the process of selecting a family member of a senior corporate officer for a job opening in the organization."; $\alpha=.82$ ).

The participants were asked to indicate the degree to which they personally considered each practice acceptable on a 7-point response scale (1 = "Totally unacceptable to me"; 7 = "Totally acceptable to me"). A composite variable was created for each dimension by averaging the pertinent items. Higher scores represent higher levels of acceptability of unethical HRM practices.

\section{RESULTS}

The data were analyzed using IBM SPSS Statistics version 22.0 software. Table 1 presents the Ms, SDs, correlations, and internal reliabilities of variables. Except for the existence of a code of ethics, the 
predictor variables show weak to moderately significant negative correlations with the acceptability of HRM practices that discriminate against and reveal a disregard for individuals.

Table 1. Means, standard-deviations, correlations, and internal reliability

\begin{tabular}{|c|c|c|c|c|c|c|c|c|c|c|c|c|}
\hline Variables & M & SD & 1 & 2 & 3 & 4 & 5 & 6 & 7 & 8 & 9 & 10 \\
\hline 1. Ethical leadership & 4.04 & 0.78 & $(.94)$ & & & & & & & & & \\
\hline 2. Scope of ethics program & 4.76 & 1.31 & $.44^{* *}$ & - & & & & & & & & \\
\hline $\begin{array}{l}\text { 3. Importance of ethics } \\
\text { program }\end{array}$ & 4.40 & 0.77 & $.51^{* *}$ & $.70^{* *}$ & $(.89)$ & & & & & & & \\
\hline 4. Employee CSR & 4.23 & 0.66 & $.68^{* *}$ & $.54^{* *}$ & $.54^{* *}$ & $(.72)$ & & & & & & \\
\hline $\begin{array}{l}\text { 5. Community and } \\
\text { environment CSR }\end{array}$ & 4.04 & 0.96 & $.66^{* *}$ & $.53^{* *}$ & $.56^{* *}$ & $.72^{* *}$ & $(.94)$ & & & & & \\
\hline 6. Economic CSR & 4.53 & 0.56 & $.58^{* *}$ & $.59^{* *}$ & $.55^{* *}$ & $.77^{* *}$ & $.52^{* *}$ & $(.69)$ & & & & \\
\hline $\begin{array}{l}\text { 7. Existence of ethics code } \\
(0=\text { No; } 1=\text { Yes })\end{array}$ & - & - & $.53^{* *}$ & - & - & $.44^{* *}$ & $.61^{* *}$ & $.33^{* *}$ & - & & & \\
\hline 8. Discrimination practices & 1.65 & 0.85 & $-.40^{* *}$ & $-.38^{* *}$ & $-.45^{* *}$ & $-.37^{* *}$ & $-.28^{* *}$ & $-.33^{* *}$ & -.07 & $(.65)$ & & \\
\hline $\begin{array}{l}\text { 9. Practices favoring those } \\
\text { in power }\end{array}$ & 2.09 & 1.05 & $-.27^{* *}$ & $-.15^{*}$ & -.06 & $-.17^{*}$ & -.08 & $-.17^{*}$ & -.02 & $.53^{* *}$ & $(.75)$ & \\
\hline $\begin{array}{l}\text { 10. Practices showing a } \\
\text { disregard for the individual }\end{array}$ & 1.59 & 0.93 & $-.43^{* *}$ & $-.55^{* *}$ & $-.63^{* *}$ & $-.53^{* *}$ & $-.32^{* *}$ & $-.51^{* *}$ & -.09 & $.61^{* *}$ & $.40^{* *}$ & $(.43)^{\mathrm{a}}$ \\
\hline
\end{tabular}

Note. $^{*} p<.05 .{ }^{* *} p<.01$, one-tailed. Cronbach's $\alpha$ in parentheses. a Pearson's correlation coefficient $p<.01$.

As for the acceptability of HRM practices favoring those in power, higher levels of acceptability of these practices are significantly correlated with smaller scopes of ethics programs and lower levels of perceived ethical leadership, economic CSR, and employee CSR. The importance given to the ethics program, the perception of community and environment CSR, and the existence of a code of ethics in the respondents' organization are not significantly related with this dimension of unethical HRM practices (all $p>.05$ ).

Given that the existence of an ethics code is not significantly related to the unethical HRM practices under study, no further analyses were performed to examine Hypothesis 1, as this received no empirical support from the data. The remaining hypotheses were subjected to linear regression analyses.

\section{Scope of Ethics Program as Predictor of Acceptability of Unethical HRM Practices}

Linear regression analysis was performed to evaluate the effect of the scope of ethics programs on the acceptability of the unethical HRM practices under study. As can be seen in Table 2, this predictor variable has a significant negative effect on the acceptability of discrimination practices (beta $[\beta]=-.38, p$ $<.000 ; \mathrm{F}[1,155]=25.718, p<.000$; adjusted R-squared $\left[\mathrm{R}^{2} \mathrm{Adj}\right]=14 \%$ ). The ethics program scope also affects practices showing a disregard for the individual $(\beta=-.55 ; p<.000 ; \mathrm{F}[1,155]=65.566 ; p<.000$; $\left.\mathrm{R}^{2} \mathrm{Adj}=29 \%\right)$ but not the acceptability of practices favoring those in power $(\beta=-.15$, not significant [n.s.]; $\mathrm{F}[1,155]=3.396$, n.s.). More specifically, the larger the scope of the organization's ethics program, the lower the respondents' level of acceptability is of discrimination and disregard for the individual in HRM practices. Therefore, Hypothesis 2 received only partial empirical support.

\section{Perceived Importance of Organizations' Ethics Programs as Predictor of Acceptability of Unethical HRM Practices}

The results of the linear regression analysis performed on the respondents' perceived importance of their organization's ethics program and the program's scope reveal that both variables predict the acceptability of two dimensions of HRM unethical practices. As shown in Table 2, perceived importance helps explain the acceptability of discrimination practices $(\beta=-.45, p<.000 ; \mathrm{F}[1,154]=39.559, p<.000$; $\left.\mathrm{R}^{2} \mathrm{Adj}=21 \%\right)$ and of practices showing a disregard for the individual $(\beta=-.63, p<.000 ; \mathrm{F}(1,154)=$ $102.877, p<.000 ; \mathrm{R}^{2} \mathrm{Adj}=40 \%$ ). However, the program's importance does not explain the acceptability of practices favoring those in power $(\beta=-.06$, n.s.; $\mathrm{F}[1,154]=0.575$, n.s. $)$. Therefore, the stronger the importance given to ethics programs, the lower the respondents' level of acceptability is of discrimination and disregard for the individual in HRM practices. Hypothesis 3 thus also received only partial empirical support. 
Table 2. Effects of Predictor Variables on Acceptability of Unethical HRM Practices

\begin{tabular}{|c|c|c|c|c|c|c|c|c|}
\hline \multirow{3}{*}{ Hypotheses } & \multirow{3}{*}{\multicolumn{2}{|c|}{ Predictors }} & \multicolumn{6}{|c|}{ Acceptability of Unethical HRM Practices } \\
\hline & & & \multicolumn{2}{|c|}{$\begin{array}{l}\text { Discrimination } \\
\text { practices }\end{array}$} & \multicolumn{2}{|c|}{$\begin{array}{l}\text { Practices favoring } \\
\text { those in power }\end{array}$} & \multicolumn{2}{|c|}{$\begin{array}{c}\text { Practices showing a } \\
\text { disregard for } \\
\text { individuals }\end{array}$} \\
\hline & & & $\mathrm{R}^{2} \mathrm{adj}$ & Beta & $\mathrm{R}^{2} \mathrm{adj}$ & Beta & $\mathrm{R}^{2} \mathrm{adj}$ & Beta \\
\hline $\mathrm{H} 2$ & \multicolumn{2}{|c|}{ Scope of ethics program } & .14 & $-.38^{* * *}$ & .02 & -.15 & .29 & $.55^{* * *}$ \\
\hline H3 & \multicolumn{2}{|c|}{$\begin{array}{l}\text { Perceived importance of } \\
\text { ethics program }\end{array}$} & .21 & $-.45^{* * *}$ & -.01 & -.06 & .40 & $-.63^{* * *}$ \\
\hline \multirow{3}{*}{$\mathrm{H} 4$} & \multirow{3}{*}{$\begin{array}{l}\text { Perceived } \\
\text { CSR } \\
\text { practices }\end{array}$} & - Employee CSR & \multirow{3}{*}{.13} & $-.27^{*}$ & \multirow{3}{*}{.02} & -.18 & \multirow{3}{*}{.30} & $-.43^{* * *}$ \\
\hline & & $\begin{array}{l}\text { - Community and } \\
\text { environment } \\
\text { CSR }\end{array}$ & & -.03 & & .09 & & .11 \\
\hline & & - Economic CSR & & -.11 & & -.07 & & $-.24^{* *}$ \\
\hline H5 & \multicolumn{2}{|c|}{ Ethical leadership } & .16 & $-.40 * * *$ & .07 & $-.27^{* * *}$ & .18 & $-.43^{* * *}$ \\
\hline
\end{tabular}

Note. ${ }^{*} p<.05 .{ }^{* *} p<.01 .^{* * *} p<.000$.

\section{Perceived CSR as Predictor of Acceptability of Unethical HRM Practices}

The next step was to examine the effects of the perceived engagement of organizations in three CSR dimensions (i.e., employee CSR, community and environment CSR, and economic CSR) on respondents' acceptability of unethical HRM practices. A set of linear regression analyses were performed in which the three predictors were considered at the same time for each dimension of the criterion variable (tolerance values $\geq .268$; variance inflation factor $\leq 3.724$ ).

The results reveal that the CSR dimensions have dissimilar effects on the acceptability of unethical HRM practices (see Table 2 above). More specifically, the acceptability of discrimination practices is only affected by the perception of CSR practices toward employees $(\beta=-.27, p<.05 ; \mathrm{F}[1,190]=10.287, p<$ $.000)$. The other CSR dimensions have no significant effect on the respondents' acceptability of discrimination practices (all $p>.05 ; \mathrm{R}^{2} \mathrm{Adj}=13 \%$ ).

As for HRM practices showing a disregard for the individual, the results indicate that two CSR dimensions help reduce the acceptability of these practices: CSR employee $(\beta=-.43, p<.000 ; \mathrm{F}[1,190]=$ $27.935, p<.000)$ and economic $\operatorname{CSR}(\beta=-.24, p<.01 ; \mathrm{F}[1,190]=10.287, p<.000)$. Once again, the perception of socially responsible practices targeting the community and environment has no significant effect ( $\left.p>.05 ; \mathrm{R}^{2} \mathrm{Adj}=30 \%\right)$.

Contrary to what was expected, no CSR dimension revealed a significant effect on the acceptability of HRM practices favoring those in power $(F[1,190]=2.316$, n.s. $)$. Overall, these results provide only partial empirical support for Hypothesis 4.

\section{Ethical Leadership as Predictor of Acceptability of Unethical HRM Practices}

The results indicate that ethical leadership has a significant negative effect on all criteria variables (see Table 2 above), explaining from $7 \%$ up to $18 \%$ of their unique variance. More specifically, ethical leadership has a negative effect on the acceptability of discrimination practices $(\beta=-.40, p<.000$; $\mathrm{F}[1,190]=36.785, p<.000)$, practices favoring those in power $(\beta=-.27, p<.000 ; \mathrm{F}[1,190]=14.675, p<$ $.000)$, and practices showing a disregard for the individual $(\beta=-.43, p<.000 ; \mathrm{F}[1,190]=43.894, p<.000)$. Overall, these results suggest that organizational members' perceptions of more ethical leadership lead them to be less prone to accept the existence of unethical HRM practices, which provides empirical support for Hypothesis 5.

\section{DISCUSSION AND CONCLUSIONS}

This study sought to understand better how some contextual factors might relate to employees' perceptions of HRM-related ethical issues in their organizations. In particular, the research was designed to investigate how non-HR professionals take into account their organization's ethical infrastructure (existence of ethics code, scope and importance of the ethics program), socially responsible practices, and supervisors' ethical leadership when these employees judge the ethicality of HR practitioners' practices.

Regarding the effects of contextual variables, the results taken as a whole appear to confirm that ethics codes and formal communication systems are insufficient to affect employees' judgements. However, the perceived importance of a system of sanctions for ethical norms violations appears to be an important factor in reducing the acceptability of ethically dubious behavior (Treviño \& Weaver, 2001). Although the results are mixed, they indicate overall that organizational environments with an extensive 
ethics program that is treated as important and a social responsibility framework seem to decrease the acceptability of unethical HRM practices.

It is worth noting that the acceptability of practices favoring those in power seems to be independent of the elements of the organization's ethical context, but it is clearly influenced by the perception of leadership ethics. It may be a similar manifestation of the tendency of organizational actors to associate the practices of leaders in favor of the powerful with self-interested motives and counterorganizational interests, as in the case of referral-based hiring practices (Derfler-Rozin et al., 2018).

Compared with the study on HR professionals' perception of the ethical acceptability of their own practices (self-perception) (Simões et al., 2019), the results of the current study show that the judgments of other organizational actors (hetero-perception) are equally affected by contextual variables. More specifically, the broader the scope of the organizations' ethics program and the stronger their perceived employee CSR, the less acceptable some unethical HRM practices are to non-HR employees.

These findings concerning HR professionals' specific activities are in line with previous research (e.g., Kaptein, 2015; Kaptein \& Schwartz, 2008; O'Fallon \& Butterfield, 2005), which indicates that, in a larger organizational context, the dynamics of ethics programs help to prevent and reduce unethical behaviors. The present results also partially support the previously proposed association between social responsibility and ethics in HRM practices (Voegtlin \& Greenwood, 2016). When employees perceive their organization as socially responsible, they show a lower level of acceptability of some unethical HRM practices. The current study's results are thus congruent with those obtained in Simões et al.'s (2019) self-perception study of HRM professionals.

The demand for ethical interventions by HR professionals most probably increases when leadership is exercised ethically. Ethical leadership is the only predictor of the acceptability of all three unethical HRM practices analyzed in the present research. This is the clearest and strongest result, confirming the importance that the literature (e.g., De Hoogh \& Den Hartog, 2009; Den Hartog, 2015) has attributed to ethical leadership in the promotion of followers' ethical behavior and the prevention of counterproductive behavior in organizations.

Globally, the present study's findings offer some guidelines for practice. First, ethics codes and formal communication systems per se seem to be insufficient to affect employees' judgements. Therefore, it is crucial that the organization develops its ethical code and formal communication system within larger ethics program and CSR strategy, both clearly communicated to and recognized by all its members. Without this full investment in these factors, the probability that organization significantly influence its members' judgment and response to ethical situations is low.

Second, findings indicate that the judgments of non-HR organizational actors about unethical HRM practices are affected by contextual variables, as it happens to HR-professional's judgements about that matters (Simões et al., 2019). As such, in practice, this finding reinforces the importance of the organization providing strong ethical cues in its spaces to positively influencing its members - both HR and non-HR professionals - judgment of unethical HRM practices. This effect will probably be extended to other type of unethical practices, thus helping to develop and reinforce an organization's ethical culture.

Finally, ethical leadership stands out from the other contextual factors here analyzed as the only predictor of the (un)acceptability of the three dimensions of unethical HRM practices. Apparently, a practical consequence to be drawn from this result is that the strategic alignment between the HRM and the other management areas will tend to safeguard the ethics of the employer-employee relationship, the stronger the degree of ethical leadership in the various units of the organization. Ethical leadership seems to be decisive in the promotion of followers' ethical judgement about HR practices, and, subsequently, ethical behavior and the prevention of counterproductive behavior in organizations in that realm (De Hoogh \& Den Hartog, 2009; Den Hartog, 2015).

Regardless of the significant findings and implications for practice offered by the present study, it has limitations that call for enhancements and corrections in future research. Further studies are needed to strengthen the psychometric qualities of measures of individuals' perceptions of HRM unethical practices. Another limitation concerns the sample composition, which shows little diversity in some sociodemographic aspects (i.e., the level of education) and which may thus affect the results' ecological validity. Besides the importance of using more heterogeneous samples, it would be also relevant to take into consideration some additional socio-professional characteristics (e.g., respondent's hierarchical position) and organizational ones (e.g., industry) in the sample composition. These can be useful for helping interpreting results.

The current study's findings also provide some clues for future research. For instance, based on research that points to an association between a HRM strategic mindset and the tendency to neglect ethical issues (e.g., Van Buren et al., 2011), a convincing reason for the apparently increasing occurrence of unethical HRM practices might be the excessive adherence to profit-oriented strategies to the 
detriment of people's wellbeing. Thus, future studies should control for the degree of HRM's alignment with organizations' strategies, namely, companies' economic and financial goals.

Because the robustness of ethical infrastructure is a precursor to the development and maintenance of ethical leadership (Eisenbeiß \& Giessner, 2012), the correlations obtained in the present study suggest that a reciprocal relationship might exist. Specifically, the degree of ethicality of leaders' behaviors and decisions may influence the way followers frame the scope and the perceived importance of the ethics program, an essential component of the organization's ethical infrastructure (Kaptein, 2011). Ethical leaders can also contribute to the perceived importance of formal components of ethics infrastructure, such as the codes of conduct, through sense-making interventions that stimulate followers' practice of and reflection on ethics. The extent and nature of this potential interaction effect also needs to be addressed in future research. Finally, given that ethical behavior and awareness have multiple determinants (Treviño et al., 2014), the possible moderating effects of pertinent intra-individual variables (e.g., moral identity and Machiavellianism) should be examined.

\section{REFERENCES}

Aguinis, H. (2011). Organizational responsibility: Doing good and doing well. In S. Zedeck, (Ed.), APA handbook of industrial and organizational psychology (pp. 855-879). American Psychological Association.

Barrena-Martínez, J., López-Fernández, M., \& Romero-Fernández, P. M. (2017). Socially responsible human resource policies and practices: Academic and professional validation. European Research on Management and Business Economics, 23, 55-61. https://doi.org/10.1016/j.iedeen.2016.05.001

Bedi, A., Alpaslan, C. M., \& Green, S. (2016). A meta-analytic review of ethical leadership outcomes and moderators. Journal of Business Ethics, 139, 517-536. https://doi.org/10.1007/s10551-015-26251

Bersoff, D. M. (1999). Why good people sometimes do bad things: Motivated reasoning and unethical behavior. Personality and Social Psychology Bulletin, 25, 28-39. http://dx.doi.org/10.1177/0146167299025001003

Brief, A. P., Dukerich, J. M., Brown, P. R., \& Brett, J. F. (1996). What's wrong with the treadway commission report? Experimental analyses of the effects of personal values and codes of conduct on fraudulent financial reporting. Journal of Business Ethics, 15, 183-198. https://doi.org/10.1007/BF00705586

Brown, M. E., \& Treviño, L. K. (2006). Ethical leadership: A review and future directions. Leadership Quarterly, 17, 595-616. http://dx.doi.org/10.1016/j.leaqua.2006.10.004

Brown, M. E., Treviño, L. K., \& Harrison, D. A. (2005). Ethical leadership: A social learning perspective for construct development and testing. Organizational Behavior and Human Decision Processes, 97(2), 117-134. http://dx.doi.org/10.1016/j.obhdp.2005.03.002

Caldwell, C., Truong, D. X., Linh, P. T., \& Tuan, A. (2011). Strategic human resource management as ethical stewardship. Journal of Business Ethics, 98(1), 171-182. https://doi.org/10.1007/s10551-0100541-y

Chugh, D., Bazerman, M. H., \& Banaji, M. R. (2005). Bounded ethicality as a psychological barrier to recognizing conflicts of interest. In D. A. Moore, D. M. Cain, G. Loewenstein, \& M. H. Bazerman (Eds.), Conflicts of interest: Challenges and solutions in business, law, medicine, and public policy (pp. 74-95). Cambridge University Press.

Cleek, M. A., \& Leonard, S. L. (1998). Can corporate codes of ethics influence behavior? Journal of Business Ethics, 17, 619-630. https://doi.org/10.1023/A:1017969921581

Dale, K. (2012). The employee as 'Dish of the Day': The ethics of the consuming/consumed self in human resource management. Journal of Business Ethics, 111(1), 13-24. https://doi.org/10.1007/s10551012-1437-9

de Gama, N., McKenna, S., \& Peticca-Harris, A. (2012). Ethics and HRM: Theoretical and conceptual analysis. Journal of Business Ethics, 111(1), 97-108. https://doi.org/10.1007/s10551-012-1479-z

De Hoogh, A., \& Den Hartog, D. (2009). Ethical leadership: The socially responsible use of power. In D. Tjosvold \& B. Wisse (Eds.), Power and interdependence in organizations (pp. 338-354). Cambridge University Press.

Den Hartog, D. N. (2015). Ethical leadership. Annual Review of Organizational Psychology and Organizational Behavior, 2(1), 409-434. https://doi.org/10.1146/annurev-orgpsych-032414111237

Derfler-Rozin, R., Baker, B., \& Gino, F. (2018). Compromised Ethics in Hiring Processes? How Referrers' Power Affects Employees' Reactions to Referral Practices. Academy of Management Journal, 61(2), 615. https://doi.org/10.5465/amj.2015.1355 
Duarte, A. P. (2011). Corporate social responsibility from an employees' perspective: Contributes for understanding job attitudes (Unpublished doctoral thesis). ISCTE-IUL, Lisbon. https://repositorio.iscte-iul.pt/handle/10071/3649

Eisenbeiß, S. A., \& Giessner, S. R. (2012). The emergence and maintenance of ethical leadership in $\begin{array}{lllll}\text { organizations. } \quad \text { Journal } & \text { Psychology, } & \text { 11(1), }\end{array}$ https://doi.org/10.1027/18665888/a000055

European Commission. (2011). A renewed EU strategy 2011-14 for corporate social responsibility, Brussels: $\quad$ EU Commission. https://eurlex.europa.eu/LexUriServ/LexUriServ.do?uri=COM:2011:0681:FIN:en:PDF

Florea, L., Cheung, Y. H., \& Herndon, N. C. (2013). For all good reasons: Role of values in organizational sustainability. Journal of Business Ethics, 114(3), 393-408. https://doi.org/10.1007/s10551-0121355-x.

Freeman, E. (1984). Strategic management: A stakeholder approach. Pitman.

Guerci, M., Radaelli, G., Siletti, E., Cirella, S., \& Shani, A. R. (2015). The impact of human resource management practices and corporate sustainability on organizational ethical climates: An employee perspective. Journal of Business Ethics, 126, 325-342. https://doi.org/10.1007/s10551013-1946-1.

Jack, G., Greenwood, M. R., \& Schapper, J. (2012). Frontiers, intersections and engagements of ethics and HRM. Journal of Business Ethics, 111, 1-12. https://doi.org/10.1007/s10551-012-1427-y.

Jamali, D. R., Dirani, A. M., \& Harwood, I. A. (2015). Exploring human resource management roles in corporate social responsibility: The CSR-HRM co-creation model. Business Ethics: A European Review, 24 (2), 125-143. https://doi.org/10.1111/beer.12085

Kaptein, M. (2009). Ethics programs and ethical culture: A next step in unraveling their multi-faceted relationship. Journal of Business Ethics, 89, 261-281. https://doi.org/10.1007/s10551-008-9998-3

Kaptein, M. (2011). Toward effective codes: Testing the relationship with unethical behavior. Journal of Business Ethics, 99, 233-251. https://doi.org/10.1007/s10551-010-0652-5.

Kaptein, M. (2015). The effectiveness of ethics programs: The role of scope, composition, and sequence. Journal of Business Ethics, 132, 415-431. https://doi.org/10.1007/s10551-014-2296-3.

Kaptein, M., \& Schwartz, M. S. (2008). The effectiveness of business codes: A critical examination of existing studies and the development of an integrated research model. Journal of Business Ethics, 77, 111-127. https://doi.org/10.1007/s10551-006-9305-0.

Kish-Gephart, J. J., Harrison, D. A., \& Treviño, L. K. (2010). Bad apples, bad cases, and bad barrels: Metaanalytic evidence about sources of unethical decisions at work. Journal of Applied Psychology, 95, 131. https://doi.org/10.1037/a0017103.

McCabe, D. L., Trevino, L. K., \& Butterfield, K. D. (1996). The influence of collegiate and corporate codes of conduct on ethics-related behavior in the workplace. Business Ethics Quarterly, 6, 461-476. https://doi.org/10.2307/3857499.

McKinney, J. A., Emerson, T. L., \& Neubert, M. J. (2010). The effects of ethical codes on ethical perceptions of actions toward stakeholders. Journal of Business Ethics, 97, 505-516. https://doi.org/10.1007/s10551-010-0521-2

McWilliams, A., \& Siegel, D. (2001). Corporate social responsibility: A theory of the firm perspective. Academy of Management Review, 26, 117-127. https://doi.org/10.2307/259398.

O'Fallon, M. J., \& Butterfield, K. D. (2005). A review of the empirical ethical decision-making literature: 1996-2003. Journal of Business Ethics, 59, 375-413. https://doi.org/10.1007/s10551-005-2929-7

Parkes, C., \& Davis, A. J. (2013). Ethics and social responsibility-do HR professionals have the "courage to challenge" or are they set to be permanent "bystanders"? International Journal of Human Resource Management, 24, 2411-2434. https://doi.org/10.1080/09585192.2013.781437.

Pinnington, A., Macklin, R., \& Campbell, T. (2007). Introduction: Ethical human resource management. In A. H. Pinnington, R. Macklin, \& T. Campbell (Eds.), Human resource management: Ethics and employment (pp. 1-20). Oxford University Press.

Rupp, D. (2011). An employee-centered model of organizational justice and social responsibility. Organizational Psychology Review, 1, 72-94. https://doi.org/10.1177/2041386610376255.

Rupp, D. E., Ganapathi, J., Aguilera, R. V., \& Williams, C. A. (2006). Employee reactions to corporate social responsibility: an organizational justice framework. Journal of Organizational Behavior, 27(4), 537543. https://doi.org/10.1002/job.380

Schwartz, M. (2001). The nature of the relationship between corporate codes of ethics and behaviour. Journal of Business Ethics, 32, 247-262. https://doi.org/10.1023/A:1010787607771

Sharma, S., Sharma, J., \& Devi, A. (2009). Corporate social responsibility: The key role of human resources management. Business Intelligence Journal, 2, 205-213. 
Simões, E., Duarte, A. P., Silva, V. H., \& Neves, J. (2019). Contextual determinants of HR professionals' selfperceptions of unethical HRM practices. European Journal of Management and Business Economics, 28 (1), 90-108. https://doi.org/10.1108/EJMBE-12-2017-0062.

Tenbrunsel, A. E., \& Messick, D. M. (1999). Sanctioning systems, decision frames, and cooperation. Administrative Science Quarterly, 44, 684-707. https://doi.org/10.2307/2667052.

Tenbrunsel, A. E., Smith-Crowe, K., \& Umphress, E. E. (2003). Building houses on rocks: The role of the ethical infrastructure in organizations. Social Justice Research, 16, 285-307. https://doi.org/10.1023/A:1025992813613.

Treviño, L. K., \& Brown, M. E. (2004). Managing to be ethical: Debunking five business ethics myths. Academy of Management Executive, 18, 69-81. https://doi.org/10.5465/AME.2004.13837400.

Treviño, L. K., \& Brown, M. E. (2014). Ethical leadership. In D. D. Day (Ed.), The Oxford handbook of leadership and organizations (pp. 524-538). Oxford University Press.

Treviño, L. K., \& Nelson, K. A. (2007). Managing business ethics (4th ed.). Hoboken, NJ: Wiley.

Treviño, L. K., \& Weaver, G. R. (2001). Organizational justice and ethics program "follow-through": influences on employees' harmful and helpful behavior. Business Ethics Quarterly, 11, 651-671. https://doi.org/10.2307/3857765.

Treviño, L. K., Brown, M. E., \& Hartman, L. P. (2003). A qualitative investigation of perceived executive ethical leadership: Perceptions from inside and outside the executive suite. Human Relations, 56, 538. https://doi.org/10.1177/0018726703056001448.

Treviño, L. K., den Nieuwenboer, N. A., \& Kish-Gephart, J. J. (2014). (Un)Ethical behavior in organizations. Annual Review of Psychology, 65, 635- 660. https://doi.org/10.1146/annurev-psych-113011143745.

Turker, D. (2009). Measuring corporate social responsibility: A scale development study. Journal of Business Ethics, 85(4), 411-27. https://doi.org/10.1007/s10551-008-9780-6

Turner, M. R., McIntosh, T., Reid, S., \& Buckley, M. (2019). Corporate implementation of socially controversial CSR initiatives: Implications for human resource management. Human Resource Management Review, 29 (1), 125-136. https://doi.org/10.1016/j.hrmr.2018.02.001

Van Buren, I., Harry J., Greenwood, M., \& Sheehan, C. (2011). Strategic human resource management and the decline of employee focus. Human Resource Management Review, 21, 209-219. https://doi.org/10.1016/j.hrmr.2011.02.004.

Voegtlin, C., \& Greenwood, M. (2016). Corporate social responsibility and human resource management: A systematic review and conceptual analysis. Human Resource Management Review, 26, 181-197. https://doi.org/10.1016/j.hrmr.2015.12.003.

Weaver, G. R., Treviño, L. K., \& Cochran, P. L. (1999). Corporate ethics programs as control systems: influences of executive commitment and environmental factors. Academy of Management Journal, 42(1), 41-57. http://www.jstor.org/stable/256873

Wooten, K. C. (2001). Ethical dilemmas in human resource management: An application of a multidimensional framework, a unifying taxonomy, and applicable codes. Human Resource Management Review, 11, 159-175. https://doi.org/10.1016/s1053-4822(00)00045-0.

Historial do artigo

Recebido $\quad 03 / 2019$

Aceite $\quad 07 / 2020$

Publicado $\quad 08 / 2020$ 